\section{An Ethnographic Approach to Peer Culture
in A Turkish Preschool Classroom \\ An Ethnographic Approach to Peer Culture
in A Turkish Preschool Classroom}

\author{
Received: 02 January 2018 \\ Revised: 14 March 2018 \\ Accepted: 26 March 2018 \\ ISSN: 1307-9298 \\ Copyright (c) IEJEE \\ www.iejee.com
}

\author{
Betül Yanıka, Mustafa Yaşarb,*
}

DOI: 10.26822/iejee.2018438139

\begin{abstract}
The purpose of this study was to examine the features of the peer culture that a group of preschoolers created in their classroom in the province of Kahramanmaraș, Turkey. An ethnographic approach was adopted in this study to obtain an in-depth understanding of children's peer interactions. The data were collected through variety of data collection methods such as participant observation, interviews, document analysis, and researcher diary for three months period. Twenty children, the classroom teacher and the other school staff participated in the study. Descriptive and qualitative content analyses were conducted to analyze the data. The results suggest that the children formed a complex culture through symbols and games to negotiate about the features of day to day interactions in the classroom. In addition, the children resisted against the influences of the teacher by turning places like the washroom and the cafeteria into a nesting area for a deeper level of personal interaction.
\end{abstract}

Keywords: Peer culture; early childhood education; interpretive reproduction; ethnographic approach

\section{Introduction}

Recently, there has been a considerable increase among the studies focusing on children's social and emotional lives. Children used to be seen as passive members of society and as wild threats that could only be controlled through education (Corsaro, 2015; Prout, 2005). The passive role that was attributed to children changed with the emergence of the constructivist theory. Corsaro and his colleagues advanced the constructivist theory by introducing the term interpretive reproduction to the child sociology field with their studies on peer interaction and culture (Corsaro, 1985, 1992, 2015; Gaskins, Miller \& Corsaro, 1992). The term, interpretive reproduction, includes the creative sides of children's' participation in the society by underlining the idea that children play an active role in both acquiring the cultural values of the society and changing the society by contributing to the culture (Corsaro, 2015; Corsaro \& Molinari, 2005). Children do not only actively participate in their society but also contribute to the change and production of the social order by carrying their daily routines and their communication styles (Corsaro, 1992). Therefore, they create their unique peer culture with the knowledge that they have acquired from the adult setting (Corsaro, 1992).

Children's peer cultures have many properties that are different from the adult or mainstream culture. Corsaro (2015) defines peer culture as "a series of activities, plays or behaviors that have become habits, toys and other materials they create together, shared values and interests that are result of peer interaction among children" (p. 125). This culture is created through the communication among children and the interaction between children and their teachers (Fernie, Davies, McCurray, \& Kantor, 2006).

Children adapt and creatively use the information they receive from the adult world to create and join their own private peer cultures to meet their interests and needs (Corsaro, 2005). The essence of a peer culture is the resistance that children hold out against the world of limitations and rules that adults set for them. The attempt to capture the control of their own lives is reinforced by the games, behaviors, and a range of activities that children have as a result of their interaction with their peers (Kantor \& Fernie, 2003). Through peer culture, children create a shared identity. This identity is structured and developed by the active solidarity of children. Thus, with this identity, children strive to gain the control of their life (Corsaro, 2015).

Peer relationships have functions such as improving social skills, socializing, developing self-esteem, making sense of their own lives, and supporting each other socially and emotionally (McDevitt \& Ormrod, 2004). As children grow older, communication skills improve and mental capacities increase, children can more easily understand the roles of others and, as a result, they can establish more effective friendship associations (Zanden, 2000). Acceptance to playgroups within peer culture and developing friendship are complex processes for children (Corsaro \& Eder, 1990). The tendency of children to protect their belongings and toys from the others makes it difficult for children to enter the playgroups of their peers (Corsaro, 1985). Children must acquire some necessary social skills in order to be accepted to peer culture.

Children discover the meaning of friendship through their games and playful activities that they engage with other children in playgrounds. To construct mutual trust and solidarity, they frequently ask each other questions like "We are friends, are not we?" (Corsaro, 2003). Corsaro (1985) has attempted to explain children's social considerations (friendship, roles, norms, status) by identifying certain characteristics of peer culture in kindergartens. Corsaro (1988) emphasizes that researchers must try to understand what it means to be a child in order to learn how children model and prepare their activities for the adult world.

Although the studies on children's peer culture are gaining importance, many of these studies have remained limited in terms of peer values, interests and identities (Corsaro, 2015). Studies in Turkey on preschool children's peer cultures are 
especially limited. In those studies, development is regarded as a linear process (Gülay, 2010; Kaytez \& Durualp 2014). In addition, the studies investigated children's lives and experiences thorough teachers' and parents' perspectives by using standardized scales (Doğanay, 1998; Erşan 2011; Inan, 2011; Kol, 2006; Şahin, 1993). This approach silenced children's voices and provided us second hand information about children. However, qualitative studies, especially ethnography, give researchers the opportunity to examine children' behaviors and relationships in their natural environments and help them to explore how children contribute to the society (Corsaro, 2015).

The purpose of this study is, therefore, to examine and explore the peer culture that a group of preschoolers created through everyday interaction in a preschool classroom. This study focused on the complex and dynamic flow of friendship relationships, which emerge in the context of peer culture.

\section{Method}

In this qualitative study, ethnographic approach was utilized to explore the socially constructed practices and experiences of children in a preschool classroom. Ethnography suits perfectly in this study because how the members of a community creates meaning and attributes meaning to specific actions or rituals within that community are difficult to reveal through mere observation from outside. This study is ethnographic because "it not only treats a social unit of any size as a whole but that ... portrays events, at least in part, from the points of view of the actors involved in the events" (Erickson, 1984, p. 52) Ethnography seems to be best way to reveal and present children's peer cultures that were often overlooked by researchers (Hoyte, Torr \& Degotardi, 2014). As Corsaro and his colleagues (Corsaro, 1985, 1992, 2003, 2015; Corsaro \& Molinari, 2005; Corsaro \& Rizzo, 1990; Gaskins et al., 1992) repeatedly demonstrated, children's peer culture is very elusive to adult perspective. Secrecy and opposition to adult rules and limitations are often considered an integral part of a peer culture (Corsaro, 2015). The best way to investigate and understand a culture is to look through the eyes of the participants in that culture. Ethnography enables the researchers to document daily lives and routines of people while exploring how participants view their world (Maggs-Rapport, 2000). In order to explore events and actions, ethnographers make "extensive definitions" rather than simply expressing things they see and hear (Corsaro, 2015; Geertz, 2006).

As participants in this study, 20 preschool children, the classroom teacher and all the school staff including one administrator, two cooks, five cleaners, and one student teacher in an independent kindergarten affiliated with the Ministry of National Education in the province of Kahramanmaraş were chosen. Twelve of the children participated in this study were male, while eight of them were female. The classroom teacher was 27 years old and graduated from a public university. He was appointed to this preschool as teacher after graduation and since then he had been working there for three years. To capture the features of the peer culture of these children the other people who worked and interacted with these children included in this study.

In this study, participant observation, semi-structured and unstructured interviews, collecting documents and researcher diary techniques were used as data collection methods. Participant observation in ethnographic studies allows researchers "participating, overtly or covertly, in people's daily lives for an extended period of time, watch- ing what happens, listening to what is said" (Hammersley \& Atkinson, 1983, p. 3). In this study the data was collected through a very unique way of participant observation. During the participant observation process, the focus was on the physical characteristics of the school and classroom, the educational program and activities, and the attitudes and behaviors of the individuals toward each other in the classroom. Additionally, the focus of observations included activities, games and routine behaviors that children developed among themselves and the values and beliefs that children shared. Instead of just joining their play and the other activities, the researcher tried to become part of the social community of the preschoolers. The researcher visited the preschool classroom three times a week during three months. When she met children first time she introduced herself as a preschool student and during the whole data collection period she followed their examples and acted as if she was six year old. The researcher completed the tasks with children that the classroom teacher assigned to them, she obeyed the rules of the classroom such as being silent or getting in line, got warned or punished when she broke the classroom rules, went to cafeteria and washroom with them, etc. An adult acting as a student like themselves did not seem real for children during the early days of the study. The children tested and questioned her during this period. The researcher made sure not to give the impression of an ordinary adult and she was gradually accepted into friendship groups. After gaining access she participated in various activities with twelve boys and eight girls. The majority of data, including photos, pictures, documents and artifacts from children's activities were collected through participant observation during this stage of the study.

The photographs illustrated children's play in different places in the school, friendship relations, objects that were popular in their peer cultures. The pictures included some intimate moments of friendship such as a girl gathering her friend's hair in the dining room, boys making funny sounds by holding their drinking water in their mouths, boys making friendship oaths by putting their hands on top of each other's hands, boys catching girls by wearing military and spiderman costumes, and some significant objects such as Ben Ten clock made of paper, and pencil cases with popular pictures for boys and girls. The documents also included children's drawings. The children draw their best friends or the super heroes of their choices.

Addition to participant observation, the researcher carried out semi-structured and unstructured interviews with all the children, the teacher and the school staff. According to Cohen (1984), ethnographic interview is different in a way that these interviews are conducted as a form of conversation in which ethnographers assume naivety and ignorance in order to understand what is being said. Most of the interviews with the children were done while the researcher and the children interacting as a part of classroom life without premeditated questions. The interviews with the classroom teacher and the school staff took place while they were engaged with their jobs. Only the school administrator was interviewed in her office. Before the interviews, an interview form was developed according to the research questions and targets of interviews. In the semi-structured interviews, the children were asked about their friendship relationships, the games they played together with the other children, their activities, and their thoughts about the classroom rules. In interviews with teachers and the school administrators, inquiries about the school education curriculum and rules, children's approach to these the school and classroom rules, and the relationships established within the school were ad- 
dressed. In the interviews with the school's staff, the staff members were asked about the relationship they established with their children, their shared moments with their children and their observations of children's interaction among each other.

Because the purpose of this study was to explore the children's peer culture, the data analysis included how the individuals were relating to each other and interacted within the classroom and school context. In this study, seventy pages of observation notes, thirty four pages of researcher diary, fifty five photographs taken during observation and pictures that children drew in the school were obtained as raw data. After the data collection process was finished, all the data were transcribed and the researchers started the coding process. The two researchers who are experts in early childhood education read the whole data repeatedly in detail by assigning codes to small data unites. After the free coding process was completed, the researchers concentrated on commonality of the themes and patterns to develop "a set of analytic categories that captured relevant aspects of these data, and the assignment of particular items of data to those categories" (Hammersley \& Atkinson, 1983, 161). After the themes were formed, relations between each other were determined and organized under the research questions. The themes obtained were; peer relations, team games, military games and superhero play, the settings that cultivated children' peer culture (cafeteria and washroom). The design of the report was carried out according to the themes and categories. While one researcher focused on field observation and data collection, the second researcher served as academic adviser and monitored all the process. During this iterative process, two researchers worked together in order to use ideas to make sense of the data and the data to make sense of ideas (Hammersley \& Atkinson, 1983).

The issues of credibility and trustworthiness were an integral part of this research process. According to Lincoln \& Guba (1985), there are three major activities to increase the probability of producing credible findings. These activities are prolonged engagement, persistent observation, and triangulation. In this study these three activities were closely interrelated. To increase the trustworthiness of the data collection process, the first precaution was to stay in the field for a longer period to engage and build rapport with participants. The researcher joined in these preschoolers' lives three days a week for a three months period. These three months not only helped the researcher to be part of the preschool classroom but also gave her opportunity to build rapport with school personnel. During this time she did persistent observation while joining children's daily life in the classroom so that the observations became both intense and focused. Triangulation of the data was achieved by gathering the data through different data sources (Hammersley \& Atkinson, 1983). In terms of triangulation of multiple methods, the researcher used observation, interviews, document analysis and researcher's diary to improve the credibility of findings. In addition to the triangulation of data collection methods, the researcher collected data during different activities, from different settings such as cafeteria and washing room, and from different informants other than children. Besides, through the researcher diary, the researcher aimed to reach a level of controlled subjectivity (Erickson, 1984) by recording her thoughts and reflections during data collection and data analysis process. Two researchers also worked collaboratively during the all stages of the study to increase the credibility of its findings

\section{Results}

The results suggest that there was a dynamic interaction between the school culture, classroom culture and children's peer culture. In the classroom, the children formed a complex culture through their friendship relationships by creating symbols and games. While the symbols created by the children helped them negotiate about the features of their day to day interactions, the team games and the war games were two important activities that shaped the nature of their peer culture. The war games and dramatic play that included popular cultural motifs such as Spiderman, Ben Ten played an important role in forming the nature of their peer culture. In addition, the children resisted against the teacher's influences by turning places like the washroom and the cafeteria into a nesting area for a deeper level of personal interaction.

\section{The school and classroom context}

The preschool that this study was conducted was a twofloor building with a wide schoolyard. The school had the capacity of one thousand students and thirty-four teachers. It was a popular school among families of high socio-economic status. Children between the ages of three and six attended to this school. Classrooms are formed according to children's ages.

There were twelve male and eight female children in the classroom. While girls preferred to play separately with their close friends, boys preferred to play in groups. Boys and girls came together only in chasing game and during gardening activities. The teacher determined all the rules of the classroom. The most important rule required children to move and talk quietly in the classroom. The children who obeyed the rules and who did not comply were rewarded and punished with the star panel prepared by the teacher. The teacher put a star on the board next to the picture of the child who obeyed the rules or took back a star from the picture of the child who obeyed the rules. According to the teacher and other staff, the school was too much family oriented and the only goal of the school was to please parents and protect the charities that collected from families. As a result, parents put pressure on teachers and the school staff about how things should be done in the school. The teachers stated that parents interfered even with classroom management and tried to inspect them. Some teachers prepared their daily activity plans according to parent demands and concentrated on reading and writing activities even though it was clearly against the suggestions of the national curriculum.

The classroom teacher who participated in this study resisted against parents' influences and structured the daily educational program by himself. The teacher determined the rules of the classroom and announced them to the children every day. The teacher prepared a star board to enforce the classroom rules and get children to follow these rules. Stars were pasted next to the photos of the children who had behaved quietly and obeyed the rules throughout the day. The teacher believed that guns and war games were harmful for children; therefore, they were banned within the classroom.

\section{Acceptance to the peer culture of children}

The study began when the researcher introduced herself to the classroom and started interacting with the children and the staff. Getting the children accept an adult as one of them in the classroom was the first challenge in this study. An adult student in a preschool classroom caused some confusion among the children during the first days 
of the study and continued drawing the children's attention the following days. While some children ignored the researcher, some girls showed some interest in the researcher. The researcher spent the first month trying to convince the children that she was not a typical adult. The children examined the researcher with various questions such as; "Why are you here? Have you ever been here? Haven't you ever been to a preschool before? If you have, why are you coming now? How old are you?" Some children thought the researcher was one of the student teachers. The researcher participated in the activities with the children in every setting. She used the same washroom to wash her hands and ate with them at the same table in the cafeteria.

Gradually, the children started to be accustomed to the presence of the researcher in the classroom and started to treat her as one of them. The children warned the researcher to obey the rules, complained about her to the teacher as they did with their other friends and started to let her join in their play. During the second month of the study, the researcher's position changed. She made a close friend in the classroom. Making a close friend increased the researcher's relationship with the other children. She witnessed the children gossiping, teasing, offending, protecting and embracing each other. After she gained access to their peer culture, the children started to reveal the secrets that they shared among their peers, the rules that organized their friendship relationships and the group rivalry, and the games that they play against the teacher's will.

\section{Friendship among children}

Identifying the important elements of the peer relationships was crucial for exploring and understanding the friendship among the children. The researcher began to observe the interactions among the children more closely. When the children were in line to go to the cafeteria, waiting in the corridor, or sitting in the cafeteria, she observed that the children pointed at each other by lifting up the thumbs. With this sign, the children indicated and confirmed their friendship. The children verbally in formed other children who they didn't want to include in their play and also expressed this intent by not showing to them their thumbs as a friendship symbol. This symbol was even more apparent during their dramatic plays. In the following note, a boy named Kutalmış was observed to give a message to another child by not showing this symbol.

Meanwhile, Kutalmış, who was playing chess, whispered to the other children "Don't be friends with Mehmet (another boy)". Mehmet was standing besides watching them. Later on Kutalmıs hid his thumb between his other fingers and showed his hand to Mehmet. Some of the other children showed their hands with their thumbs up. Kutalmıs said "No, you have to do it like this" and made them hide their thumbs. Mehmet then went to draw a picture.

The children confirmed their friendships not only with the thumb symbol but also by verbally expressing it. They asked each other "We're friends, right? We're pals, right?" to confirm their friendships. Here is a following example observed two girls in the girls' washroom.

\footnotetext{
PInar (P): You're my friend, aren't you?

Eda (E): Yes.

$P$ : But you didn't sit next to me.

E: I didn't because the teacher said so. I will sit next to you later on, okay?
}

The term friendship was used among the children for different purposes. The children used the term friendship to decide who would join their play. A child who was not let in a play asked the others "But aren't I your friend?" and insisted on playing with them. Friendship allowed the children to share the toys and gifts and built solidarity among them. Some children were observed to give offers like "If you be my friend I will give you my play dough". The children who were close friends gave picture gifts to each other and shared their personal belongings (soap, play dough, pencils). In addition, they gave their belongings to each other and reserved seats in the cafeteria for their friends.

Close friends were staying very close to each other and supporting each other different ways. They opened up their friend's page during reading activities or tied up their friend's hair when it became undone. They asked the teacher to give stars to their friends who couldn't win any stars. Sometimes, they expressed their support as a group and by putting their hands on each other yelled out "Allfor-one, one-for-all". In order to entertain themselves the children played language games and made fun with their friends. In the cafeteria they made fun with word plays like "Burnt author, Roasted author" because the researcher's surname meant "burnt" in Turkish.

While they confirmed their friendship verbally or with symbols, sometimes they tested their friendship by sitting apart, not talking or showing some resentment. They also talked behind a friend when they got offended and whispered to each other's ears. These resentments lasted for a short time and friendships resumed without any apparent changes.

\section{Team games for boys}

The peers' attempts to gain the classroom control caused some conflicts within the classroom. In order to understand these conflicts, it is crucial to clarify concepts such as status quo and power relationships within the classroom. The boys' attempts to gain the control of the classroom became explicit when they started to play team games. The researcher observed during the first month how the children were making play offers to each other and trying to join a game. However, it became apparent later that play relationships were not simple or superficial; they were rather structured in a complex way. The researcher observed two different boy groups who made a team and started competing against the other group. Two leaders of the teams, Kutalmıs and Özgür, strived to pull the other children into their groups and also to sustain their authorities within the groups. They used water bottles as symbols to identify their team. The children of the same team put their water bottles side by side. The children who did not have a water bottle were not included in either team. The researcher also tried to be a member of one of the teams. Here is a dialogue between the team leader and the researcher:

The researcher: Which one is your team?

Özgür: Our team is over there (pointing to the other children) The researcher: Can I join in your team as well?

Özgür: No, you don't have a water bottle.

The researcher decided to obtain a water bottle to become a member of the group. The following dialogue expresses this:

Researcher: Then if I bring my water bottle tomorrow can I join the team?

Özgür: No, you can't be in our team. You're a girl.

Researcher: Why, can't girls join your team?

Özgür: No, girls join the girls' team. 
The researcher talked with other team members to convince the leader. When the team leader Özgür was finally convinced, he said "Well, okay. But get yourself a water bottle. But make sure it's one for girls!" When researcher asked how girl water bottles looked like, Özgür showed her the water bottles with girl pictures. Next day, the researcher brought a water bottle with a spider-man on it, instead of a girl water bottle that the leader had told her to bring. This became a joking matter among the children and they started to say "Author brought herself a boy water bottle" "Author is a boy" and showed it to each other. Bringing a boy water bottle to the school did not please the team leader, but with the help of the other members he let her in the team. When the researcher joined boys teams the other girls got interested and they also wanted to join in the teams. The following dialogue between a team leader (Özgür) and two girls illustrated this request of the girls.

Tuba and Ayça: We want to join in your team as well.

Özgür: No, you can't, girls aren't allowed.

Tuba: But author is a girl.

Özgür: But she's a big girl. We let big girls in the team.

When they entered the third month of the study the researcher became a member of a boy team and got the opportunity to observe their conflicts closer. She witnessed the toy exchanging fight that broke out between the two teams frequently. These fights often ended when some children complained the teacher about the children of the other team. The teacher advised the children to share the toys and warned them not to misbehave. However, the following note shows how the team leaders continued this rivalry:

Mehmet: Teacher, Özgür won't let me play with the toys.

The teacher: Özgür, you're not the only one who can play with those toys.

Özgür: Okay, come here my friend.

Mehmet goes near Özgür.

Özgür: If you want to be among our team you have to sit beside me.

Mehmet: Okay

The members of the teams continuously changed alliances with the groups and went in-and-out between the two teams. The boys sometimes left the team with their own will and sometimes they were kicked out. It was the team leaders who decided who would join the team and who would be expelled. With this power, the team leaders threatened the members to exclude from the team and influenced them as they wished. The group members explained this as "playmaker is the boss of the play" and agreed to follow the leader. Some girls were not interested with the boy teams, the other girls were interested but they were not allowed to join in these teams.

\section{War games and superhero play}

The children showed great interest in war games even though war games were banned by the teacher. They played these games in places where the teachers' control was less obvious. When the teacher caught them playing such games in the classroom, he reminded them that "No guns are allowed in this classroom. These games are not suitable to play. In this classroom we give each other roses." However, despite the teachers' warnings, the children continued these games by making guns out of Legos and fruit juice straws. During the interviews, the children stated that they filled fruit juice straws with sand and fired with them at each other. Some of the children said "This gun fires fruit juice. This is a fruit juice gun" and tried to explain it to the teacher. When one of the children was asked about war games, he explained "we put on masks, throw our webs and fight the evils". Both teams waged war against each other in these games and blamed the opposite team of being evil. On interviews about the team leader children said that there are two Spiderman in the classroom, but that one was evil. Just like the team games, in order for the girls to join in the war games, they had to fulfill some requirements. The girls were allowed to join in the games if they knew how to throw a web and if they did what the team leader asked them to do. In war games, the boys chased the girls as if they were spider-men and the girls tried to escape from them.

Although the war games were banned by the teacher, the teacher let the children bring some materials closely related to comic book or cartoon characters such as Spiderman and Ben Ten to the classroom. Some of the boys came to school with a Spiderman outfit or a Ben Ten watch. Some children lent their Ben Ten t-shirts to each other claimed that girls fell in love with them when they wore these outfits. The following dialogue illustrates this:

Aykut (boy): See that girl is in love Kutalmıs.

Researcher: Who said so?

Aykut: The girls did.

Researcher: What did they say?

Kutalmış (boy): They only looked at my Spiderman costume

The children who didn't have Ben Ten watches made watches out of sticky papers behind books. Two children started doing these paper watches, but soon it spread around the school and many children started to wear those paper watches.

The settings that cultivated children's peer culture

The children created plays and activities in every setting in the school. However, the children carried out their peer interactions and communications mostly in the cafeteria and the washrooms. The washrooms and the cafeteria became a nest for their peer culture. The common feature of these settings was that they were the places where the teacher's control was the least evident. The children used various settings during in this study in order to decrease the control that adults imposed on them. In a way, the peer culture helped the children to resist against the rules and the control of adults.

Although the cafeteria was commonly accepted as the place where the children met their physical needs, it had another function for the peers. Here, the children threw their metal plates at each other from under the tables, showed their personal belongings to each other, filled their mouths with tissues and tried to talk, made mustaches and beards from the ayran and bread, made weird noises with the fruit juice, peeled mandarins and played around with them. They also played word games and teased each other. "Hello, I'm Mr. Penny bank. I will beat you if you throw money in me" or put the words fork, spoon and other words in front of their names and repeat sentences. The children would race each other to sit at the end of the table and be distant from the teacher who sits at the front end of the table. Some children felt they were under the inspection every minute and this was evident in their behaviors. The following dialogue from the cafeteria illustrates this:

Tuba (T) (girl): See, did you know that there's a camera over there.

Researcher (R): Really?

$T$ : Yes, if you don't finish your plate they see from that camera and write it in your school report. The principal told us. In fact, I don't eat desserts at home, l eat it here.

$R:$ Why?

T: I don't like desserts, but I eat because they're watching us. 
Like the cafeteria, the children used the washroom for other functions related to the peer culture. They asked permission from the teacher to go to the washroom, but they would play over there instead. During the interviews, the cleaning personnel said that the children would go to the washroom to play and hide each other's belongings. In the washrooms, the children communicated with their peers from other classrooms; they made bubbles from soap and played with them. They used the rubbish bin instead of the toilet bowl; they hid their personal belongings and they wet each other. The woman in charge of cleaning the washrooms stated that:

For example I say, Kerem (boy), what are you doing here, go wash your hands and don't wait. He's taking time, playing, talking. I want him to wash his hands and go, I don't want him to keep waiting. Children like playing there; they do something with the water, soap and the toilet bowl. They don't come to the washrooms for the need to use the washroom but they come here to play. They sit and run away. They come by saying they are in need and return without using the toile or washing their hands pretending that they used the toilet.

\section{Discussion}

The results of this study suggest that children form friendship relationship by creating symbols, rituals and solidarity among themselves similar to how adults do. Peer relationships of children are not so different from those of adults (Garvey, 1984). Just like adults, children focus on themes such as trust, solidarity and sharing (Corsaro, 2015). Friendship and love can be observed openly among preschool children (Madrid, 2007; Sebanc, 2003). During play children gain insights about other people and learn how to share, collaborate and express their feelings (Wilson, 2008).

In this study, the children were observed to make word plays by putting different words in front of their names and created some language game rhymes. A study on Italian children also found that the children made effective discussions among themselves and made tongue-incheek challenges during these discussions (Corsaro \& Molinari, 2006). This was also observed on African girls while they were skipping rope (Goodwin, 2006), in Taiwanese children's routine language games (Hadley, 2003) and Italian children's verbal activities which they called "cantilena" (Corsaro \& Rizzo, 1990). These language games help children improve their language and communication skills (Pramling \& Samuelsson, 2013). Language games among children include rhymes, alliteration, laughing, analogy, imitation and absurd poetry (Pramling \& Samuelsson, 2013).

In this study, the children used some of the peer culture elements to manage their relationships in the classroom Who was going to join in their play was one of the focal issues among the children's interaction. These children created some symbols to exclude the other children from their play and formed some secret symbols to indicate close friendship. Research on peer relationships suggests that most of the problems among peers happen during the stage of acceptance to the peer group (Moon, 2001). Although many teachers and parents consider that excluding other children in play as a selfish and non-cooperative act, this act does not always mean that children show resistance against the idea of sharing or refuse cooperation. This kind of resistance has often some functions in creating the imaginative play and, consequently, forming the relationships among children (Corsaro, 2015).

According to Corsaro, (2015), the essence of peer culture centers around the idea of gaining one's own autonomy from adult authority and rules. The children in this study often showed resistance against the classroom and school culture. These children resisted against teacher's prohibitions by turning restricted places like the washrooms and the cafeteria into a nesting area for their peer culture. Similar situation that children prefer areas that are away from adults was observed in the study of Skånfors, Löfdahl, \& Hägglund (2009). They found that the children created secret hiding places. The boys, as in this study, chose the toilets for this purpose and tried to lock the door, while the girls found a small room and put a chair behind the door to prevent intruders.

Another setting where the children tried to gain power and control is the imaginative play. Superhero play have always entertained and attracted children and found almost every aspect of preschool routines and activities (Galbraith, 2007). The need for control and power in children is recognized by scholars and superhero play is seen as an important venue to meet this need (Boyd, 1997, Galbraith, 2007). Superhero play helps children not only to gain acceptance but also to develop a place for themselves in a group (Boyd, 1997). Stone's (2008) study underlined that superhero play can help some children overcome their fears and develop self-esteem and confidence. In addition, teachers can utilize superhero play to motivate children for different chores that children are often reluctant to do such as putting away their toys or eating broccoli (Bauer \& Dettore, 1997).

However, educational counselors and families believe that superhero play includes violence and can negatively affect child development and should be prohibited (Galbraith, 2007). Boyd (1997) observed that children preferred to play superhero games in places where the teacher could not see them. While most teachers prohibit war toys and games in their classrooms (Doliopoulou, 1998), research indicates that prohibition and restrictions make unwanted behaviors even more attractive (Rogers \& Evens, 2008). When parents prohibit their children to use toy guns, they noticed that children start using their body parts (e. g. fingers) or sticks or brooms as weapons in their play (Doliopoulou, 1998). In addition, playing games that prohibited by their adults makes children feel guilty and lie more (Bauer \& Dettore, 1997).

The classroom teacher participated in this study did not perceive war games and superhero play as educative and positive; as a result he banned them in the classroom. The classroom teacher prohibited such games and did not allow toys used as guns and weapons. In fact, by doing so, the teacher ignored and excluded an important part of the peer culture that was developing in his classroom. However, this prohibition was ineffective within these peer culture and these were frequently evident in children's' play. Against the teacher's will, the boys created teams and played war games and superhero play in the classroom.

A teacher should allow children to express their interests rather than banning them and should recognize peer culture elements as a part of the learning environment of the classroom. They should include them in the system rather than ignoring or excluding them (Cook, 2001). It is crucial for teachers to understand peer culture in order to resolve conflict between peers and to increase educational efficiency. Teachers can create a balance between school culture and peer culture by observing their children to reveal the features of peer culture and by using these features while planning their own curriculum. By joining children's play, teachers can not only improve their play but also promote their overall development (Carlsson-Paige \& Levin, 1987). Thus, the negative and counter-productive effects 
of peer culture that children can introduce to the classroom can be reduced.

\section{Conclusions}

This study provides a window for preschool classrooms where multiple cultures often coexist and most of the time conflict each other. The peer culture is often overlooked and its power underestimated by teachers and scholars alike while they focus mostly on how teachers should act and what kind of classroom environment is more efficient. Looking closely in children's lives and their interactions with adults and peers provides us a new understanding about how children live and what goes on in classrooms. Because children's peer culture is very elusive to adult perspective, further studies on peer culture will both enhance our understanding and help children's voice to be heard.

\section{References}

Bauer, K. L. \& Dettore, E. (1997). Superhero play: What's a teacher to do? Early Childhood Education Journal, 25(1), 17-21.

Bodrova, E., \& Leong, J., D. (2005). Uniquely preschool: What research tells us about the ways young children learn. Educational Leadership, 63(1) 44-47.

Boyd, B. J. (1997). Teacher response to superhero play: To ban or not to ban? Childhood Education, 74(1), 2328.

Carlsson-Paige, N. \& Levin, D. E. (1987). The War Play Dilemma: Balancing Needs and Values in the Early Childhood Classroom. Teachers College Press, Teachers College, Columbia University, New York, NY 10027.

Cohen, A. P. (1984) Informants. In R.F. Ellen (Ed.), Ethnographic research: A guide to general Conduct (pp. 223-229). London: Academic Press.

Corsaro, W., (1985). Friendship and peer culture in the early years. Norwood, NJ: Ablex.

Corsaro, W., (1992). Interpretive reproduction in children's peer cultures. Social Psychology Quarterly, 55, 160177.

Corsaro, W., (2003). "We're friends, right?" Inside kids' culture. Washington, DC: Joseph Henry Press.

Corsaro, W., (2015). The sociology of childhood . (Fourth Edition). Thousand Oaks, CA: Sage.

Corsaro, W., \& Eder, D., (1990). Children's peer cultures. Annual Review of Sociology, 16, 197-220.

Corsaro, W., \& Molinari, L., (2005). I compagni: Understanding children's transition from preschool to elementary school. New York: Teachers College Press.

Corsaro, W., \& Molinari, L., (2006). From seggiolini to discussione: the generation and extension of peer culture among Italian preschool children. International Journal of Qualitative Studies in Education 3(3), 213-230.

Corsaro, W., \& Rizzo, T. (1990). Disputes in the peer culture of American and Italian nursery school children. In A. Grimshaw (Ed.), Conflict talk (pp.21-66). New York: Cambridge University Press.
Denzin, N. K., \& Lincoln, Y. S. (2000) Introduction: The discipline and practice of qualitative research. N. K. Denzin \& Y. S. Lincoln (Eds) Handbook of qualitative research. Second Edition. (1-30) Thousand Oaks: Sage Publications.

Doğanay, J. (1998). Anasınıfına devam eden çocukların ebeveynlerinin çocuk oyun ve oyuncakları hakkındaki görüşlerinin incelenmesi [An investigation of the views of parents whose children attend kindergarten regarding children's play and toy preferences]. Yüksek Lisans Tezi, Ankara Üniversitesi Fen Bilimleri Enstitüsü: Ankara.

Doliopoulou, E. (1998). Preschool children's war play: How do Greek teachers and parents cope with it ?. European Early Childhood Education Research Journal, $6(1), 73-86$.

Erickson, F. (1984). What makes school ethnography 'Ethnographic'? Anthropology and Education Quarterly, 15(1), 51-66.

Erşan, Ş. (2011). Okul öncesi eğitim kurumlarında görev yapan öğretmenlerin ilgi köşelerinde serbest oyun etkinlikleri ile ilgili görüş ve uygulamalarının incelenmesi [An investigation of the views and practices of preschool teachers on free time activities in interest corners in the classroom]. Doktora Tezi, Gazi Üniversitesi Eğitim Bilimleri Enstitüsü: Ankara

Fernie, D., Davies, McMurray, P.B., \& Kantor, R., (2006). Becoming a person in the preschool: Creating integrated gender, school culture, and peer culture positionings. International Journal of Qualitative Studies in Education, 6, 95-110.

Galbraith, S., J.(2007). Multiple perspectives on superhero play in an early childhood classroom. Unpublished Dissertation, Graduate School Of The Ohio State University.

Garvey, C. (1984). Children's talk. Cambridge, MA: Harvard University Press.

Gaskins, S., Miller, P. J., Corsaro, W. A. (1992). Theoretical and methodological perspectives in the interpretive study of children. New Directions for Child Development, 58 .

Geertz, C. (2006). Kültürlerin yorumlanması [The interpretation of cultures]. (Çev. Hakan Gür) Ankara: Dost Kitapevi.

Goodwin, M. (2006). The hidden life of girls: Games of stance, status and exclusion. Malden, MA: Blackwell.

Gülay, H. (2010). Okul öncesi dönemde akran ilişkileri [Peer relationships in preschool period]. Ankara: Pegem Akademi.

Hadley, K. (2003). Children's word play: Resisting and accommodating Confucian values in a Taiwanese kindergarten classroom. Sociology of Education, 76, 193-208.

Hammersley, M. \& Atkinson, P. (1983). Ethnography. Principles in practice (3rd ed.). London: Routledge.

Hoyte, F., Torr, J., \& Degotardi, S. (2014). The language of friendship: Genre in the conversations of preschool children. Journal of Early Childhood Research, 
$12(1), 20-34$.

İnan, Z. (2011). Özel okul öncesi eğitim kurumları yönetici ve öğretmenlerinin oyun seçimi hakkındaki görüşleri [The views of private preschool administrators and teachers on children's choice of play]. Yüksek Lisans Tezi, Yeditepe Üniversitesi Sosyal Bilimler Enstitüsü: İstanbul.

Kaytez, N. \& Durualp, E. (2014). Türkiye'de okul öncesinde oyun ile ilgili yapılan lisansüstü tezlerin incelenmesi [An investigation on thesis conducted in Turkey on preschool children's play]. Uluslararası Türk Eğitim Bilimleri Dergisi, 2(2). 110-122.

Kol, S. (2006). Okul öncesi öğretmenleri ile yöneticilerinin bilgisayar destekli oyun programlarının kullanımına yönelik algı ve beklentileri. [The perception and expectation of preschool teachers and administrators on the use of computer supported game programs. Yüksek Lisans Tezi, Sakarya Üniversitesi Sosyal Bilimler Enstitüsü: Sakarya.

Lincoln, Y. S. \& Guba, E. (1985). Naturalistic inquiry, Beverly Hills, CA: Sage.

Maggs-Rapport, F.(2000). Combining methodological approaches in research: ethnography and interpretive phenomenology. Journal of Advanced Nursing, $31(1), 219-225$.

Madrid, S. (2007). Emotional themes in preschool children's play narratives. Unpublished dissertation. The Ohio State University. Retrieved from https://etd. ohiolink.edu/

McDevitt, T. M. \& Ormrod, J. E. (2004). Child development: Educating and working with children and adolescents. Nj: Pearson prentice- hall.

Moon, M. (2001). Teacher perspectives on peer relation problems of young children. Asia Pacific Education Review, 2(1), 22-31.

Pramling, N. \& Samuelsson, P. I. (2013). Language play: The development of linguistic consciousness and creative speech in early childhood education. In I. Schousboe \& D.W. Lindqvist (Eds), Children's play and development: Cultural-historical perspectives (pp.127-139). London: Springer

Prout, A. (2005). The future of childhood. London: Routledge.

Rogers, S. \& Evans, J. (2008). Inside role-play in early childhood education: Researching young children's perspectives. New York: Routledge.

Sebanc, A. M. (2003). The friendship features of preschool children: Links with prosocial behavior and aggression. Social Development, 12(2), 249-268.

Skånfors, L., Löfdahl, A. \& Hägglund, S. (2009). Hidden spaces and places in the preschool: Withdrawal strategies in preschool children's peer cultures. Journal of Early Childhood Research, 7(1), 94-109.

Stone, A., L. (2008). Superhero play among preschool children. Unpublished Master's Thesis. The Faculty Of Humboldt State University.

Şahin, F. (1993). Üç-altı yaş grubu çocuklarının anne ba- balarının çocuk oyun ve oyuncakları hakkındaki görüşlerinin incelenmesi [An investigation on views of parents whose children are in ages between three and six on children's play and toy preferences] Yüksek Lisans Tezi, Hacettepe Üniversitesi, Ankara.

Wilson, R. (2012). Nature and young children: Encouraging creative play and learning in natural environments. New York: Routledge. 